\title{
CRP からみた深頸部膿場の遷延化因子
}

\author{
國井 美羽・鹿野 真人*・松塚 崇 \\ 小川 洋・大森 孝一 \\ Clinical Factors in the CRP-positive Period in \\ Prolonged Cases of Deep Neck Abscesses
}

\author{
Miha Kunii, Takashi Matsuzuka, Hiroshi Ogawa and Koichi Omori \\ (Fukushima Medical University School of Medicine) \\ Makoto Kano \\ (Ohara General Hospital)
}

\begin{abstract}
Some cases of deep neck abscesses are severe with prolonged inflammation. From December 1994 to December 2006, thirty-four patients with deep neck abscesses were treated in the Department of Otolaryngology, Fukushima Medical University. The CRP-positive period was used as an indicator of the duration of inflammation in our study. The relationships between the duration of inflammation and the clinical factors were examined.

There was a mutual relationship (coefficient of correlation: 0.86 ) between the CRP-positive period and the duration of hospital stay. There was little relationship between the CRP-positive period and the factors of sex, past history, and detected bacteria; however, there was a significant relationship between the CRP-positive period and the factors of age, cause of infection, antibiotics, tracheotomy, and inflammation expanding to the mediastinum. Elderly cases were prone to be prolonged and cases treated with two antibiotics had a tendency to be prolonged. In cases of tonsillar infections, tracheotomy, and inflammation expanding to the mediastinum, the duration of inflammation was prolonged.

From our results, we should select suitable treatments for patients with clinical factors resulting in prolonged inflammation.
\end{abstract}

Key words : clinical factors, CRP, deep neck abscesses

はじめに

深頸部膿瘍は深頸筋膜間に存在する間隙に感染が波及 することで発生する炎症性疾患で, 抗菌薬が発達した近 年でも重症化・遷延化して生命にかかわる深刻な状態に 陥ることがある. 深頸部膿瘍の発症因子や重症化因子に ついては，これまで高年齢，糖尿病，歯原性疾患や特定 の細菌が関連するといら報告がなされている. 今回われ われは 1994 年 12 月から 2006 年 12 月までの 12 年間に当 科で入院し,外科的治療を行った梁頸部膿瘍 34 症例につ いて，CRP が陰性化するまでの期間（CRP 陽性期間）を
炎症持続期間すなわち遷延化の指標として扱い, 各臨床 因子が遷延化に及ぼす影響について調べた（表 1).

\section{対象}

1994 年 12 月から 2006 年 12 月までの 12 年間に当科に 入院し,外科的治療を行った深頸部膿瘍は 34 症例であっ た。文象からは頭頸部癌症例を除いた。深頸部膿瘍の部 位は顎下間隙, 副咽頭間隙, 咽後間隙に膿瘍貯留を認め たものとし扁桃周囲膿瘍単独症例は今回の対象症例から 除いている. 性別は男性 20 例, 女性 14 例, 年齢は 2 歳 
から 82 歳をでの平均 49 歳で 10 歳以下が 4 例, 20 歳代 1 例, 30 歳代 3 例, 40 歳代 7 例, 50 歳代 8 例, 60 歳代 が 4 例, 70 歳代 6 例, 80 歳代が 1 例であった.

\section{方 法}

1. 対象症例の治療過程において初診時あるいは入院 時からの CRP が陰性化 (CRP $\leqq 0.3 \mathrm{mg} / \mathrm{dl}$ ：ラテックス 凝集免疫測定法）するまでの期間を CRP 陽性期間とし， 入院日数との相関を調べた. すべての症例が治癒退院で あり, 発熱のないこと, 経口捸取可能であること, 気管 切開例では気管孔が閉鎖されていることが退院条件と なっている.

2. CRP陽性期間と下記の臨床因子との関連を調べた.

1）年齢，性別，2）基礎疾患，3）原因疾患，4）検出 菌，5）入院時の CRP 值，6）縦隔膿瘍への進展，7）抗 菌薬，8）気管切開術の有無

\section{3. 統計処理}

2.の関連性を判定するための検定法は, 本研究では症 例数が比較的少なくデータ分布が正規分布とみなすこと ができない，もしくは離散值データであるためノンパラ メトリック検定 (Mann-Whitney のU 検定および KruskalWallis 検定）を用いた。 ノンパラメトリック検定では一 般に平均值でなく中央値を用いる.

\section{結 果}

1. CRP 陽性期間と入院日数

CRP 陽性期間は 2 日から 48 日であり,平均は 14 日で あった。

また，入院日数は 16 日から 108 日でその平均は 32 日 であった. 縱隔膿瘍を併発した 4 例など 8 例が 40 日を超 過した. 入院日数は CRP 陽性期間と相関を示した（相関 係数 0.86$)$.

2. CRP 陽性期間と各臨床因子

1）年齢，性別

年齢を 60 歳以上の高年齢群 11 例とそれ以外の群 23 例 としたとき, 2 群間の CRP 陽性期間中央值はそれぞれ 16 日，11 日で有意差を認めた。男性 20 例と女性 14 例では CRP 陽性期間中央值はそれぞれ 12 日, 13.5 日で有意差は 認めなかった。

\section{2）基礎疾患}

基礎疾患としては 7 症例（21\%）が糖尿病を有してい た. 糖尿病を有した 7 症例の CRP 陽性期間は中央值 15
日，糖尿病を有さない 27 症例では中央值 12 日であり， 両者に有意差は認めなかった。 なお，成人 Still 病で長期 間ステロイドを内服していた 1 例が含まれていたが，こ の症例では頸部膿瘍罹患以前のステロイド内服期間での CRP は陰性で, 罹患時には CRP は上昇し膿瘍治療後には CRP は陰性化した。

3）原因疾患

原因疾患が判明した症例は 25 例 $(74 \%)$ であった。内 訳は扁桃関連疾患（急性扁桃炎，扁桃周囲炎，扁桃周囲 膿瘍）が 12 例（35\%）ともっとも多く，歯原性疾患（う 蝕症, 歯根炎）が 6 例 (18\%), 喉頭蓋炎, 顎下腺炎およ びリンパ節炎がそれぞれ 2 例ずつ $(6 \%)$ ，耳下腺炎が 1 例（3\%）であった。異物が原因となったものや外傷性・ 医原性症例は認めなかった。原因の判明しない症例は 9 例 (26\%) であった。扁桃関連疾患の CRP 陽性期間中央 值は 16 日，歯原性が 8 日，喉頭蓋炎などその他の原因が 中央値 13.5 日であった。 症例の多い扁桃関連疾患, 歯原 性疾患について調べたところCRP陽性期間に有意差を認 め，扁桃関連疾患の方が有意に遷延していた。

4) 検出菌

好気性菌検出が 19 例 (56\%), 嫌気性菌検出が 6 例 (19 $\%)$,これらのらち好気性菌と嫌気性菌の両方が検出され た例が 2 例（6\%）であった．培養陰性は 8 例（24\%）, 未検は 1 例であった。好気性菌の内訳は Streptococcus 属 が 11 例, Staphylococcus 属が 6 例, Neisseria 属が 4 例, Corynebacterium 属と Brucella 属が1例ずつであった. 嫌気 性菌の内訳は Peptostreptococcus 属が 6 例, Bacteroides 属 とVeillonella 属が 1 例ずつであった (のべ検出数). 好気 性菌検出例, 嫌気性菌検出例, 培養陰性例の 3 者間で CRP陽性期間の中央值はそれぞれ13日, 12日, 10日であっ たが，3 群間に明らかな有意差は認められなかった. 菌 が検出された症例のうち11例については感受性試験がな されていないか感受性試験にない薬剤を選択されていた が, その他 14 例については感受性のある薬剤が選択され ていた. いずれの群も CRP 陽性期間は中央值 13 日であ り，有意差を認めなかった。 なお，多剂耐性菌は認めら れなかった。

5）入院時の CRP 值と CRP 陽性期間および入院期間 入院時の CRP 值と CRP 陽性期間 $(r=0.54)$, また CRP 值と入院日数 $(\mathrm{r}=0.45)$ はデータ数と比較して弱い相関 があると認められた。

6）縱隔への進展 
表 1 CRP 陽性期間と臨床因子

\begin{tabular}{|c|c|c|c|c|c|c|c|c|c|c|c|c|c|}
\hline 症例 & 年齢 & 性別 & $\begin{array}{l}\text { 入院 } \\
\text { 日数 }\end{array}$ & $\begin{array}{l}\text { CRP } \\
\text { 陽性 } \\
\text { 期間 }\end{array}$ & 入院時 & 原因疾患 & 基礎疾患 & 検出菌 & 使用抗菌薬 & $\begin{array}{c}\text { 使用抗菌薬 } \\
\text { に対する } \\
\text { 感受性 }\end{array}$ & $\begin{array}{c}\text { 気管 } \\
\text { 切開の } \\
\text { 有無 }\end{array}$ & $\begin{array}{l}\text { 切開 } \\
\text { 回数 }\end{array}$ & $\begin{array}{l}\text { 縦隔膿瘍 } \\
\text { ドレナージ }\end{array}$ \\
\hline 1 & 6 & 女 & 25 & 2 & 0.5 & 不明 & - & - & FMOX & & - & 2 & - \\
\hline 2 & 55 & 女 & 19 & 3 & 5.2 & 歯原性 & 糖尿病 & Klebsiella Pneumoniae & $\mathrm{PAPM} / \mathrm{BP}$ & $S$ & - & 1 & - \\
\hline 3 & 35 & 男 & 24 & 6 & 2.2 & 扁桃周囲膿瘍 & イレウス & - & CTRX & & + & 1 & - \\
\hline 4 & 50 & 男 & 24 & 7 & 27.6 & 歯原性 & - & Pept. prevoti, Veiollonella & CFSL+CLDM & S & + & 1 & - \\
\hline 5 & 6 & 男 & 16 & 8 & 6.5 & 歯原性 & - & Sta. aureus & $\mathrm{PAPM} / \mathrm{BP}$ & S & - & 1 & - \\
\hline 6 & 20 & 男 & 17 & 8 & 13.2 & 喉頭蓋炎 & - & Pept. spp & MEPM+CLDM & - & - & 1 & - \\
\hline 7 & 34 & 女 & 26 & 8 & 21.1 & 歯原性 & - & $\begin{array}{l}\text { Strept. viridans, Neisseria } \\
\text { Pept. morbillorum, Pept. micros }\end{array}$ & $\mathrm{PAPM} / \mathrm{BP}$ & - & + & 1 & - \\
\hline 8 & 57 & 男 & 21 & 8 & 4.2 & 不明 & 糖尿病 & Candida glabrata & CTRX+CLDM & - & - & 1 & - \\
\hline 9 & 82 & 女 & 20 & 9 & 8.7 & 顎下腺炎 & - & Strept. viridans & CLDM & S & - & 1 & - \\
\hline 10 & 46 & 男 & 20 & 9 & 5.6 & 不明 & 成人 Still病 & Burkholderia cepacia & CTRX+CLDM & S & - & 1 & - \\
\hline 11 & 47 & 女 & 28 & 10 & 14.9 & 不明 & 高血圧 & Neisseria & $\mathrm{PAPM} / \mathrm{BP}+\mathrm{CLDM}$ & - & - & 1 & - \\
\hline 12 & 71 & 男 & 42 & 10 & 12.1 & 歯原性 & - & - & CFSL+CLDM & & - & 1 & - \\
\hline 13 & 45 & 男 & 18 & 10 & 14.7 & 歯原性 & - & Streptococci.spp & FMOX+CLDM & - & - & 1 & - \\
\hline 14 & 40 & 男 & 15 & 11 & 21.3 & 不明 & - & Strept. constellatus & MEPM & S & + & 1 & - \\
\hline 15 & 53 & 女 & 31 & 12 & 29.7 & 扁桃周囲炎 & - & $\begin{array}{l}\text { Strept. constellatus, Pept. micros } \\
\text { Bacteroides }\end{array}$ & CFPM+CLDM & $S$ & - & 1 & - \\
\hline 16 & 57 & 男 & 17 & 12 & 8 & 扁桃炎 & - & - & MEPM & & - & 1 & - \\
\hline 17 & 63 & 男 & 37 & 12 & 25.9 & 扁桃炎 & $\begin{array}{l}\text { うっ血性心 } \\
\text { 不全 } \\
\text { 慢性腎不全 }\end{array}$ & - & $\mathrm{PAPM} / \mathrm{BP}$ & & + & 1 & - \\
\hline 18 & 2 & 女 & 31 & 13 & 23.3 & 不明 & - & Strept. viridans, Neisseria. & $\mathrm{PAPM} / \mathrm{BP}+\mathrm{CLDM}$ & - & - & 1 & - \\
\hline 19 & 51 & 男 & 17 & 13 & 37.8 & 扁桃周囲炎 & 高血圧 & Neisseria, Corynebacterium & FMOX+CLDM & S & + & 1 & - \\
\hline 20 & 74 & 男 & 17 & 14 & 19.2 & 耳下腺炎 & $\begin{array}{l}\text { 糖层病, } \\
\text { 肝硬変 }\end{array}$ & $\begin{array}{l}\text { Sta. epidermidis } \\
\text { Strept. viridans group }\end{array}$ & $\mathrm{CAZ}$ & S & + & 1 & - \\
\hline 21 & 52 & 女 & 43 & 14 & 38.1 & 不明 & 胃潰瘍 & Pept. spp Prevotella. intermedia & CAZ & - & + & 1 & + \\
\hline 22 & 47 & 男 & 21 & 15 & 11.1 & $\begin{array}{l}\text { 顎下部リンパ } \\
\text { 節炎 }\end{array}$ & 糖尿病 & Sta. aureus (MSSA) & $\mathrm{PAPM} / \mathrm{BP}+\mathrm{CLDM}$ & S & - & 2 & - \\
\hline 23 & 78 & 女 & 26 & 15 & 29 & 喉頭蓋炎 & $\begin{array}{l}\text { 糖尿病, } \\
\text { 高血圧 }\end{array}$ & Streptcoccus & FMOX+CLDM & - & + & 1 & - \\
\hline 24 & 62 & 女 & 42 & 16 & 68.6 & 扁桃周囲膿瘍 & 糖尿病 & - & $\mathrm{PAPM} / \mathrm{BP}+\mathrm{CLDM}$ & & + & 2 & - \\
\hline 25 & 68 & 男 & 53 & 16 & 19. 6 & 扁桃周囲膿瘍 & C 型肝炎 & Staphylococcus & MEPM+CLDM & - & + & 1 & - \\
\hline 26 & 40 & 男 & 38 & 17 & 42.9 & 扁桃周囲膿瘍 & - & 未検 & $\mathrm{SBT} / \mathrm{CPZ}+\mathrm{CLDM}$ & - & - & 1 & - \\
\hline 27 & 38 & 男 & 38 & 17 & 41.6 & 顎下腺炎 & - & Sta. epidermidis & FMOX + CLDM & S & + & 1 & - \\
\hline 28 & 48 & 男 & 42 & 18 & 52.6 & 急性扁桃炎 & 糖尿病 & Strept. viridans, CNS & FMOX + CLDM & - & + & 1 & - \\
\hline 29 & 72 & 女 & 36 & 18 & 31.3 & 扁桃周囲膿瘍 & & $\begin{array}{l}\text { Strept. viridans, Neisseria } \\
\text { Strept. non haemolyticus }\end{array}$ & $\mathrm{PAPM} / \mathrm{BP}+\mathrm{CLDM}$ & - & + & 1 & - \\
\hline 30 & 4 & 女 & 29 & 19 & 5 & $\begin{array}{l}\text { 顎下部リンパ } \\
\text { 節炎 }\end{array}$ & - & Sta. aureus & FMOX+CLDM & S & - & 1 & - \\
\hline 31 & 58 & 男 & 46 & 19 & 14.2 & 不明 & 肝機能障害 & - & PAPM/BP+CLDM & & + & 1 & + \\
\hline 32 & 73 & 男 & 42 & 22 & 36.9 & 扁桃周囲膿瘍 & - & Peptostreptococcus. & FMOX+CLDM & S & + & 1 & - \\
\hline 33 & 79 & 女 & 63 & 23 & 22.9 & 不明 & - & Streptococci. & MEPM+CLDM & S & + & 1 & + \\
\hline 34 & 69 & 女 & 108 & 48 & 14.8 & 急性扁桃炎 & - & - & $\mathrm{PAPM} / \mathrm{BP}+\mathrm{CLDM}$ & & + & 1 & + \\
\hline
\end{tabular}

Pept. $=$ Peptostreptococcus Sta. $=$ Staphylococcus Strept. =Streptococcus S : 感受性あり - : 感受性テスト施行せず $\mathrm{FMOX}=$ flomoxef $\mathrm{PAPM} / \mathrm{BP}=$ panipenem/betamipron $\quad \mathrm{CTRX}=$ ceftriaxone $\mathrm{CFSL}=$ cefoselis $\mathrm{CLDM}=$ clindamycin $\quad \mathrm{MEPM}=$ meropenem $\quad \mathrm{CFPM}=$ cefepime $\quad \mathrm{CAZ}=$ ceftazidime $\mathrm{SBT} / \mathrm{CPZ}=$ sulbactam/cefoperazone 
これらの症例の中で縦隔膿瘍を併発し縦隔ドレナージ を必要とした症例は 4 例 $(12 \%)$ であった. そのうち 1 例は左膿胸もあったため胸腔ドレナージを外科と協力し て施行した. 縦隔膿瘍を併発した 4 症例の CRP 陽性期間 は中央值 21 日であり, 併発しなかった 30 症例での CRP 陽性期間中央值 12 日に比較し有意に長かった。

7) 抗菌薬

23 例 $(68 \%)$ で 2 骭が併用されていた。 ペネム系とク リンダマイシンの併用が 10 例 (29\%) であり,フロモキ セフとクリンダマイシン併用が 7 例 $(21 \%)$ ，第 $3 \cdot 4$ 世 代セフェム系とクリンダマイシン併用が 6 例（18\%） で あった．単剤投与では，ペネム系が 6 例 $(18 \%)$ ，第 3 ・ 4 世代セフェム系が 4 例（12\%)，クリンダマイシンが 1 例 $(3 \%)$ であった. 2 剂を併用した 23 症例と単剂投与 11 症例とでは CRP 陽性期間はそれぞれ中央值 15 日，9 日であり，有意差を認めた。

8）気管切開術の有無

気管切開術を 18 例 (53\%) に施行した. 気管切開術を 施行した 18 例と非施行 16 例での CRP 陽性期間はそれぞ れ中央值 15 日，10日であり，有意差を認めた。

\section{考察}

深頸部膿瘍の臨床経過における診断や治療, 発症およ び重症化因子について考察された報告はあるが1)～3）炎 症の遷延化にどのような臨床因子が関与するかを調べた 報告は少ない. 今回われわれは初診時から CRP が陰性化 するまでの日数（CRP 陽性期間）を，深頸部膿瘍の炎症 の遷延化の指標として用いた. 当科における深頸部膿瘍 症例で CRP 陽性期間と入院日数の関係を調べたところ, 高い相関関係を認めた（相関係数 0.86）。しかしながら, 入院日数には炎症が消失した後の原疾患治療やリハビリ など他の要因が入ることが考えられる，そこで本研究で は, これらの他の要因の影響を少なくするために CRP 陽 性期間を指標として用いた。

次に, CRP 陽性期間とさまざまな臨床因子との関連を 調べた。

患者背景因子として高齢であることが深頸部膿瘍症例 の中で予後増悪因子もしくは重症化因子になるという報 告と ${ }^{23)}$ そうはならないとする報告がある11. 高齢である ことが重症化因子になるという報告 ${ }^{2) 3)}$ では死亡例に高 齢者が多いことから重症化因子であるとしている. 今回 の対象では, 60 歳以上の群と 60 歳未満群の 2 群間にお
いてCRP陽性期間で有意差を認めることから炎症の遷延 化因子となると判定できた. 性別については CRP 陽性期 間で有意差を認めなかった.

基礎疾患については糖尿病をもつ症例が 34 例中 7 例 (21\%) であり，日本人成人の糖尿病有病率は $7.8 \%$ とい われておりこれと比較しても高率であった，糖尿病症例 ではその易感染性が深頸部膿瘍の発症因子として重要で あるとされる2). 一方で, 糖尿病は必ずしも重症化因子 とはならないとの報告がある ${ }^{3) 4}$. 当科での糖尿病群の CRP陽性期間は糖尿病を有さない群と有意差は認められ ず，糖尿病を基礎疾患として持つことが炎症の遷延化因 子になるとは判定できなかった. ただし, 糖疗病症例の らち 2 例では 2 回切開排膿術が行われており，このよう な例では糖尿病の存在が遷延化に影響を及ぼした可能性 はある。

原因疾患については歯原性疾患（歯根炎，う触症）の ものが米国では多く (43\%) 報告されており5), また歯 原性からの頸部膿瘍が重症化する傾向があるとの報告も ある ${ }^{4)}$. 今回の対象では歯原性のものは 6 例 (18\%), CRP 陽性期間の中央值は 8 日であり他の疾患に比較してとく に長くはなく，遷延化傾向があるとはいえなかった，症 例数のもっとも多かった扁桃関連疾患ではCRP陽性期間 の中央值は 16 日であり, 歯原性疾患のものに比べて遷延 化傾向があった.

検出菌については好気性菌が検出された群, 嫌気性菌 が検出された群, 培養陰性の 3 群で CRP 陽性期間に有意 差は認めず, 本研究では好気性か嫌気性か培養陰性かが 遷延化に関与しているかは判定できなかった．検出菌の 種類についてはその多くが Streptococcus 属, その中でも 口腔連鎖球菌がその $69 \%$ 占めていた. 口腔連鎖球菌は 一般に病原性が高いわけではないが，Streptococcus 属の 中でも深頸部膿瘍に関連すると報告されている ${ }^{6}$ milleri groupは当施設では検出されず, また菌種同定にまで至ら ない例も認められた。. また, 菌が検出された症例のうち 11例については感受性試験がなされていないか感受性試 験にない薬剤が選択されていたが, その他 14 例について は感受性のある薬剤が選択されていた. 両群で CRP 陽性 期間には有意差を認めず，感受性を証明できずに選択し た抗菌薬でも炎症の遷延化はきたさず，明らかに不適切 な選択はなかったものと考えられる。

入院時の $\mathrm{CRP}$ 值と $\mathrm{CRP}$ 陽性期間, また CRP 值と入院 日数には弱い相関関係が認められた. 初診時の CRP の值 
で炎症の遷延化が予測されらるものの，今回検討してい るようなそれ以外の要因に左右されるのではないかと考 えられた。

治療法としては, 外科的切開排膿術が全例で施行され, それとともに抗菌薬が投与されていた。深頸部膿瘍が診 断された初期の段階，つまり培養結果が明らかでない時 点で第 $3 \cdot 4$ 世代セフェム系やパニペネムとクリンダマイ シンを併用する報告は多くみられる778)。当科でも 2 郕併 用例がその多くを占めていたが，単剤投与群と比較して CRP 陽性期間は有意に遷延していた.このことは, 2 剂を 併用することの治療効果が低いといらょりは，炎症が遷 延するような重症例に対して抗菌薬 2 剤を併用したので はないかと考えられた。一般に報告されているように9 感染症治療の基本方針としては, 菌が明らかでない臨床 初期には広いスペクトラムの抗菌薬を十分な量で投与 し，菌が検出された時点でスペクトラムに見合う抗菌薬 に変更するという作業が重要である. 今回の対象症例に ついてもこの方針に則って抗菌薬は選択されていたと考 えられた。

切開排膿術と同時に気管切開術を行った例は 18 例 (53 \%) であり，気管切開を施行しない 16 例に比べて CRP 陽性期間が有意に長く, 炎症の遷延化ありと判定された。 これは気道閉塞の危険が予測される重症例に気管切開が 施行されたこと, また, 気管周囲の操作による炎症の波 及などによるものなどが考えられた。深頸部膿瘍では気 道狭窄をきたしやすく，喉頭内視鏡所見などにより気管 切開術の施行を決定することが重要であり ${ }^{10)}$, また, 切 開排膿術を行う場合には気管前間隙や頸動脈間隙の操作 などで喉頭浮腫を引き起こさないように慎重な操作が必 要である.

縱隔膿瘍を併発し頸部切開排膿に際して縦隔ドレナー ジを併施した例は 4 例存在した. 縦隔ドレナージを行っ た 4 例はその他の 30 例より有意に CRP 陽性期間が延長 し炎症が遷延化していた. 縱隔への炎症の波及が CRP 陽 性期間の延長にかかわっていると考えられた. 当科では 死亡例は認めなかったが縦隔進展して死亡した報告例は 少なくなく233)，外科との連携のうえで縦隔ドレナージを 行い厳重な経過観察が必要と考えられる.

\section{まとめ}

当科で診断加療した深頸部膿瘍症例について, CRP 陽 性期間を炎症の遷延化を示す指標として扱い，各臨床因
子が遷延化にどのように関与しているかを調べた。 その 結果, 性別, 糖尿病の有無, 検出菌の種類については炎 症の遷延化との関連は認めなかった。 高年齢, 原因疾患 が扁桃関連疾患か歯原性疾患か, 気管切開術の有無, 縱 隔への進展は有意に炎症の遷延化と関連を認めた.

今回の結果から得られた炎症の遷延化因子やその可能 性について念頭に置いたらえで, 症例に応じた適切な治 療を選択することが重要と考えられた。

\section{謝辞}

稿を終えるにあたり, 統計評価に関してご指導いただきまし た福島県立医科大学医学部公衆衛生学講座, 後藤あや先生に深 く感謝いたします。

本論文の要旨は, 第69回耳鼻咽喉科臨床学会学術講演会 $(2007$ 年 7 月，東京）に押いて発表した。

\section{参考文献}

1）石永 一, 加藤昭彦, 山田弘之：頭頸部膿瘍 79例の臨床的 検討. 耳鼻臨床 $91: 1063 \sim 1067,1998$.

2）梁本克彦, 市川銀一郎：進展した深頸部感染症の治療一文 献的考察一. 耳鼻臨床 $88: 773 \sim 779,1995$.

3）安藤敬子, 佐藤公輝, 田淵伴秀: 深頸部膿瘍の 3 例. 耳鼻 と臨 $38: 214 \sim 219,1992$.

4) 那須 隆, 小池修治, 稲村博雄, 他 : 深頸部感染症の臨床 的検討. 耳鼻臨床 $96: 919 \sim 924,2003$.

5) Har-El G, Aroesty JH, Shaha A, et al. : Changing trends in deep neck abscess. A retrospective study of 110 patients. Oral Surg Oral Med Oral Pathol 77 : 446 450, 1994.

6）藤吉達也, 吉田雅文, 牧嶋和見, 他: 深頸部膿瘍における Streptococcus milleri groupの検出頻度とその病原性. 日耳鼻 会報 $104: 147 \sim 156,2001$.

7）長内洋史, 川堀眞一, 原㴊保明, 他：扁桃周囲炎後の咽後 膿瘍症例. 耳鼻と臨 $47: 179 \sim 184,2001$.

8）越野樹典, 小川克二, 山本一博, 他：呼吸困難を呈した咽 後膿瘍の1例. 耳鼻・頭頸外科 $71: 131 \sim 133,1999$.

9）青木 眞: 抗菌薬の投与量, 投与経路, 投与間隔. 感染症 診療マニュアル. 24〜 33頁, 医学書院, 東京, 2000 .

10）木村美和子, 中嶋正人, 二藤隆晴, 他 : 頸部外切開を要し た深頸部膿瘍症例の検討. 日気管食道会報 $57: 14 \sim 19$, 2006.
原稿受付：平成20年 1 月 17 日

原稿採択：平成 20 年 5 月 8 日

別刷請求先：國井美羽

テ960-1295 福島市光が丘 1

福島県立医科大学医学部耳鼻咽喉科学講座 